\title{
Tunnevoimaa työyhteisöihin
}

\section{Isokorpi Tia \& Viitanen \\ Päivi (2001). Tunne- \\ voimaa! TAMMI}

\section{Tunteiden vaikutus}

ihmisten motivoitumiseen ja toisaalta uupumiseen työssä on kiistaton. Sen sijaan kiistanalaisempi on viime vuosina alkanut tunneälyn, tunnetaitojen ja tunnevoimavarojen esiinmarssi työelämän koulutusmarkkinoille. Kaikki tiedostavat näiden taitojen merkityksen, mutta koulutuksellisesti ollaan harmaalla maaperällä. Tähän maaperään tämäkin teos on suunnattu. Se lupaa, että tunnetaitoja voi oppia ja että tunnetaitojen hallitseminen työssä merkitsee todellista huippuosaamista.

\section{Lupaamiaan tavoitteita} teos lähtee lunastamaan esittelemällä alkuun tutkittua tietoa tunteista. Lähdeviitteineen kirjan alkuosa on kuin tutkimusraporttia, ja käsitteiden määrittely alkaa uuvuttaa melko pian. Toisaalta se takaa uskottavuutta: kun kirjoitetaan aiheesta, josta amerikkalaista populaarikirjallisuutta riittää, kannattaakin panostaa tarkkuuteen!

\section{Luku Tunteet työelämän} opettajana on mielenkiintoinen. Se lähtee liikkeelle tutuista perusasioista: oppimista vahvistavat myönteiset tunteet opittavaa asiaa, tilannetta ja ryhmää kohtaan. Pelko lamaannuttaa oppimisen. Työyhteisön tunnemaailma onkin jo vaikeampi juttu. Kirjassa esitetään, että esimiehen on oltava sinut itsensä kanssa. Totta tosiaan. Mutta onko työntekijöillä kaikilla tasoilla runsaasti tunneongelmia? Kehittämistyössä tunteille pitää antaa tilaa, työyhteisön jäseniä pitää kannustaa ilmaisemaan tunteitaan, ja tunneilmasto pitäisi saada turvalliseksi. Kirjan sanoma tunteiden merkityksestä kiteytyy lauseeseen: elämä ilman tunteita on merkityksetöntä. Kuvittelen mielessäni vaikkapa insinöörien tiimikoulutuksen, jossa tavoitteena on oppia ilmaisemaan tunteitaan. Enpä haluaisi vetää sellaista! Kun tunnekirjassa edetään työyhteisön muutoksiin, esitetään, että vähiten uupumusta esiintyy työyhteisöissä, joissa kuunnellaan henkilöstön tunteita. Näihin väittämiin olisi kaivannut myös perusteluja tai lähdeviitteitä tutkimuksista. Etteivät vaan olisi uskomuksia?

Kirja antaa tässä kohden kuin ohimennen ohjeita työpaikoille: erityisesti kielteisten tunteiden ilmaisua on tuettava. Muutos esitetään tässäkin kirjassa prosessimallin avulla. Sen mukaan työelämän muutokset organisaatiotasolla alkavat hämmennyksestä ja päättyvät uudelleen suuntautumiseen monien tunteita herättävien vaiheiden jälkeen. Tätä mallia voi kyseenalaistaa sillä perusteella, että työelämässä eletään tätä nykyä jatkuvien muutosten aikaa - vain muutos on pysyvää. Niinpä olennainen kysymys jaksamisen kannalta saattaakin olla se, että edistävätkö muutokset työn hallintaa vai eivät? Tällä kriteerillä arvioituna muutoksia ei voi niputtaa samaan, ei myöskään niitä prosesseja, joita ihmisissä herää muutostilanteissa.

\section{Kirjan puolessä välissä} edetään tunnetaitojen oppimiseen. Kirjoittajatat esittelevät ns. tuta-mallin. Tunnetaitoja opetellaan siten, että opetellaan hallitsemaan uusia menettelytapoja tilanteisiin, jotka eivät toimi. Toiseksi harjoitellaan soveltamaan uutta menettelytapaa mahdollisimman usein sekä käytännössä että ajatusleikein. Kolmantena metodina käytetään roolinvaihtoja, joissa käydään läpi vaikeita tilanteita toisten oppijoiden kanssa. Neljäntenä keinona on pyytää palautetta toverilta, joka seuraa aktuaalia tilannetta vierellä. Tuta-mallia on sovellettu ammattikorkeakouluissa niinkin teknispainotteisilla aloilla kuin tekniikassa, siinä aikuisopiskelijoiden koulutuksessa. Opiskelijoiden mielestä oli hyvä, että sellaisia aiheita käsiteltiin koulutuksessa. Tuta-mallissa edetään tunnetaitojen opiskelussa viiden eri tason kautta: fyysiset tunnehavainnot, omien tunteiden tiedostaminen, omien tunteiden hallinta, tunnevoimalla tavoitteeseen ja tunteiden sosiaalisuus.

Tekijät yhdistävät lopuksi tunnetaitojen oppimisen kokemuksellisen oppimisen malliin. Siinä vaiheessa aiheen käsittely palasi vankalle maaperälle. Kokemuksista oppimisen prosessi on käyttökelpoinen malli myös ns. pehmeiden kvalifikaatioiden oppimisessa. Tämä osio oli kirjan paras osuus.

Arto Pietikäinen 